\title{
Patient and procedural features predicting early and mid-term outcome after radical surgery for non-small cell lung cancer
}

\author{
Garofano N, Ellenberger C, Triponez F, Diaper J, Bridevaux P.- \\ O, Karenovics W, Licker M.
}

\author{
Department of Anaesthesia \\ Geneva University Hospitals, Geneva, Switzerland
}

\section{Background}

Postoperative cardiovascular and pulmonary complications (PCVCs and PPCs) are frequent and associated with prolonged hospital stay (1-3). In this study, we aimed to update the risk factors associated with major complications and survival after lung cancer surgery.

\section{Methods}

- Post-hoc analysis of a randomized controlled trial assessing the impact of preoperative rehabilitation (3).

151 patients undergoing lung cancer resection

- Inclusion criteria:

- Adult patients with non-small cell lung carcinoma stage III A or less

Exclusion criteria :

- Contraindication or inability to adhere to a rehabilitation program

- Patients were allocated into 2 groups:

- Usual care $(n=77)$

- Rehabilitation with 2-3 training sessions/week, over 2-3 weeks preceding surgery $(n=74)$

- Preoperative tests included pulmonary function and DLCO

- Six Minute Walk Test and symptom-limited CPET were performed twice (at enrolment and day before surgery)

- Standard blood tests : $\mathrm{N}$ terminal brain natriuretic peptide (biomarker of ventricular dysfunction)

- Primary endpoint : early mortality rate (in-hospital or 30 days after surgery), incidence of major PCVCs and PPCs and mid-term survival after surgery

\section{References}

(1) Licker M et al. Eur J Cardiothorac Surg. 1999

(2) Serpa Neto A, et al. Lancet Respir Med. 2014

(3) Licker M et al. J Thoracic Oncol 2016

\section{Results}

Early mortality rate was $2.6 \%$. Logistic regression analysis showed that PCVCs (15\%) were associated with elevated plasma levels of NT-pro-BNP (odds ratio [Ors] 6.0, 95\% confidence interval [Cl] 1.3 to 27.3) and performance of a pneumonectomy $(\mathrm{OR} 9.6,95 \% \mathrm{Cl} 2.9$ $31.5)$ whereas PPCs (33\%) were associated with COPD (OR $5.9,95 \% \mathrm{Cl} 2.4$ to 14.8 ), blood transfusion (OR 5.2, $95 \% \mathrm{Cl} 1.2$ to 23.3 ) and current smoking (OR 2.6, $95 \% \mathrm{Cl} 1.1$ to 6.5 ). Preoperative rehabilitation was considered a protective factor regarding PPCs (OR $0.13,95 \% \mathrm{Cl} 0.05$ to 0.34 ).

As shown in table 1, poor survival after surgery was associated with inefficient ventilation (ratio of ventilation to carbon dioxide at exertion [VE/VCO2 slope] $>40 \mathrm{~L} / \mathrm{min}$ ), the presence of coronary artery disease, elevated NT-pro-BNP plasma levels and the occurrence of PPCs.

\begin{tabular}{|c|c|c|c|}
\hline \multicolumn{4}{|c|}{ Cox regression analysis of factors associated with poor survival after lung cancer surgery } \\
\hline & $\begin{array}{l}\text { Hazard } \\
\text { Ratio }\end{array}$ & $\begin{array}{l}95 \% \text { Confidence } \\
\text { Interval }\end{array}$ & $P$ \\
\hline $\mathrm{V}_{\mathrm{E}} / \mathrm{VCO}_{2}>40 \mathrm{~L} / \mathrm{min}$ & 8.28 & $3.39-20.23$ & $<0.001$ \\
\hline Preop Coronary Artery Disease & 3.34 & $1.33-8.37$ & 0.010 \\
\hline Preop NT-pro- BNP > 100pg/ml & 3.40 & 1.22-9.47 & 0.019 \\
\hline $\begin{array}{l}\text { Postoperative Pulmonary } \\
\text { Complications }\end{array}$ & 2.72 & $1.16-6.35$ & 0.021 \\
\hline
\end{tabular}

\section{Conclusions}

- Modifiable risk factors (aerobic capacity, smoking, transfusion) in addition to the extent of surgery and baseline cardiac function are predictive of PCVCs and/or PPCs.

- Mid-term survival after curative lung cancer resection is related to baseline ventilatory efficiency $\left(\mathrm{V}_{\mathrm{E}} / \mathrm{VCO}_{2}\right.$ ratio), the presence of cardiac disease and the occurrence of PPCs. 